\title{
Surface Active Properties of Marine Humic Acids
}

\author{
Shigeo Hayano, Noriko Shinozuka, and Masao Hyakutake \\ Institute of Industrial Science, University of Tokyo \\ (22-1, Roppongi 7-chome, Minato-ku, Tokyo)
}

\begin{abstract}
The surface tension of various humic acid solutions was measured. The marine humic acids exo tracted with $0.5 \mathrm{~N} \mathrm{NaOH}$ from the marine sediments sampled from Suruga Bay and Sagami Bay show high surface activity compared to the commercially available terrestrial humic acids. From the relation between surface tension and marine humic acid concentration, the surface tension decreases linearly with the logarithmic concentration and becomes constant value of about $40 \mathrm{dyn} / \mathrm{cm}$ at the concentration of $0.1 \%$. This bending point at $0.1 \%$ is removed to the lower concentration by addition of salts like an ionic surfactant. The presence of a bending point and salt effect to it may suggest the association of marine humic acids.

The marine humic acids were fractionated by ultrafiltration and the surface tension of each fracs tion was measured. The results show that the higher molecular weight fractions, which occupy $75 \%$ of the sample, exhibit high surface activity: bending points are also observed for their surface tensionconcentration curves at $0.1 \%$.

The high performance liquid chromatographic analysis of humic acids by use of three kinds of gel indicates that the humic acid is a mixture of compounds molecular weight of which are widely ranged. The chromatographic results of molecular size distribution agreed on the whole with those of fracs tionation by ultrafiltration. From chromatograms of marine humic acids, the higher molecular weight fraction seems to be less hydrophilic and this weak hydrophilic character may cause the surface activity of them.
\end{abstract}

\section{Introduction}

Humic substances are probably the most wide= ly distributed natural organic products on the surface of the earth ${ }^{1}$. The bulk of the organic matter in most soils, waters, and marine sedic ments consists of humic substances. They are usually classified into three fractions; 1) humic acid, which is soluble in dilute alkaline solution but is precipitated by acidification, 2) fulvic acid, which is soluble in dilute alkaline and dilute acid solutions, and 3) humine, which can not be extracted by alkaline and acid solutions ${ }^{2}$.

Thus widely distributed humic substances (humic and fulvic acids) are thought to play a very significant role on the circulation of sub= stances in the environment. For a long time, studies on humic substances had been carried out from the standpoint of soil science. While recently, particular interest has focused on the marine humic substances in relation to the mas rine pollution. Boem and Quinn ${ }^{3)}$ reported that the humic substances in the sea water and the fulvic acid extracted from a marine sediment increased solubility of $n$-alkanes and isoprenoids into saline water. Chen and Schnitzer ${ }^{4}$ mea= sured surface tension of solutions of humic and fulvic acids extracted from soil and found that these acids lowered the surface tension of water significantly. Rochus and Sipos ${ }^{5}$ reported the critical micelle concentration of black humic acids extracted from browncoal.

The purpose of our investigation is to make clear the role of humic and fulvic acids in the sea and to find the possibility to utilize them against marine pollution. In this paper, we in = tend to study the surface active behavior of marine humic acids, which have been extracted from the marine sediments and characterized by chemical analysis, IR and ${ }^{13} \mathrm{CNMR}$ spectra in our laboratory ${ }^{6), 7)}$. Attention is given to the molecular size effect on the surface activity of humic acids. 


\section{Experimental}

\subsection{Extraction of Humic Acid}

The sampling sites and sampling procedure were the same as reported before ${ }^{6)}$. The frozen marine sediment was brought to room temperature and was passed through a 80 mesh sieve to remove shells and bricks, then it was acidified with $\mathrm{HCl}$ to $\mathrm{pH} 2$ to remove $\mathrm{CaCO}_{3}$ from shells. After washed with water, humic acid was extracted into $0.5 \mathrm{~N} \mathrm{NaOH}$ using mag= netic stirrer for $24 \mathrm{~h}$ at $30^{\circ} \mathrm{C}$. This extraction procedure was repeated three times and the solution was centrifuged to eliminate the sus= pending mud, then filtered with $0.45 \mu \mathrm{m}$ mil= lipore filter. Acidified the filtrate to $\mathrm{pH} 2$ with $6 \mathrm{~N} \mathrm{HCl}$, the resultant humic acid pre= cipitated was centrifuged and collected. Dissos lution and precipitation with $6 \mathrm{~N} \mathrm{NaOH}$ and 6 $\mathrm{N} \mathrm{HCl}$ respectively, were repeated three times and the precipitate was washed with dilute $\mathrm{HCl}$ until sodium was not detected by flame test. The purified humic acid was dried on a Teflon dish in a vacuum desiccater with phosphorus pentoxide. Commercially available humic acids (Aldrich and Wako Ltd. s) were purified by the same procedure. To eliminate saponin and bitumen, the humic acid was washed with meth= yl alcohol three times followed by washing with petroleum ether three times.

\subsection{Measurement Procedure}

The surface tension of humic acid solution was measured with a Wilhelmy type surface tensiometer (ST-1, Shmadzu Seisakusho Ltd.) The temperature was controlled at $25 \pm 0.5^{\circ} \mathrm{C}$. The $\mathrm{pH}$ values of the solutions were around 8 .

The ultrafiltration was carried out with an ultrafiltration apparatus (Bioengineering Co., MC-2) with membranes (Amicon Co.) of XM300 (cutoff molecular weight, c.m.w., 300,000), XM-100 A (c.m.w. 100,000), PM-30 (c.m.w. 30,000), and PM-10 (c.m.w. 10,000). The pressure of $1.5 \mathrm{~kg} / \mathrm{cm}^{2}$ was applied with high quality $\mathrm{N}_{2}$ gas. The procedure was as follows; $2 \mathrm{~g}$ of sample humic acid was dissolved into 100 $\mathrm{ml}$ water. After allowed to stand for a day, the solution was centrifuged at $17000 \mathrm{rpm}$ for 60 $\min$ at $25^{\circ} \mathrm{C}$. The supernatant was concentrated with $\mathrm{XM}-300$, then added $50 \mathrm{ml}$ of $\mathrm{pH} 10 \mathrm{Na}=$ $\mathrm{OH}$ solution. The filtrate was treated with
$\mathrm{XM}-100$. These sequences were repeated to the last filter, PM-10. Each fraction was dried on a Telfon dish in a $\mathrm{P}_{2} \mathrm{O}_{5}$ vacuum desiccater.

A high performance liquid chromatograph (TRI ROTAR, Japan Spectroscopic Co.) and an ultraviolet absorption detector (UVIDEC 100, Japan Spectroscopic Co.) were used with poly= styrene porous polymer gels of Hitachi-3011 S, 3011 S 35 and 3011 O 36 packed in stainless steel columns. Sulfonate groups were involved for 3011 S gel, while 3011 S 35 and 3011 O 36 were synthesized as larger pore size gels of $3011 \mathrm{~S}$, and attached of $-\mathrm{SO}_{3}{ }^{-}$and $-\mathrm{CH}_{2} \mathrm{OH}$ group, respect $=$ ively. The sample volume injected was $10 \mu \mathrm{l}$ of $0.1 \%$ solution. $0.5 \mathrm{~N} \mathrm{Na}_{2} \mathrm{CO}_{3}$ was used as an eluent solution; elution rate was $1.0 \mathrm{ml} / \mathrm{min}$.

\section{Results and Discussion}

\subsection{Surface Tension Measurement of Marine Humic Acids}

The sampling location and elementary com = positions are listed in Table-1 together with the results of commercially available humic acids which are thought to be of terrestrial origin by the following reasons; 1) Their absorption specs tra in the visible wave length region lack a shoulder absorption band at about $410 \mathrm{~nm}$, which is characteristic to marine humic acids. 2) From the elementary analysis and the functional group analysis ${ }^{6}$, they show typical terrestrial character, Aldrich's is classified to B type soil humic acid according to the definition by $\mathrm{Ku}=$ $\operatorname{mada}^{8}$. The three marine humic acids have similar elementary composition, while commers cial humic acids showed the lower percentage in $\mathrm{H}$ and $\mathrm{N}$.

Table-1 Elementary composition of humic acids.

\begin{tabular}{|c|c|c|c|c|c|}
\hline Sample & Sampling site & $\begin{array}{c}\text { Depth } \\
(\mathrm{m})\end{array}$ & $\begin{array}{c}\mathrm{C} \\
(\%)\end{array}$ & $\begin{array}{c}\mathrm{H} \\
(\%)\end{array}$ & $\begin{array}{c}\mathrm{N} \\
(\%)\end{array}$ \\
\hline Sagami-2 & $3457.2^{\prime} \mathrm{N} 13915.6^{\prime} \mathrm{E}$ & 1333 & 47.9 & 4.8 & 4.8 \\
\hline $\mathrm{ST}-\mathrm{Z}-12$ & $3448.4^{\prime} \mathrm{N} 13830.1^{\prime} \mathrm{E}$ & 970 & 49.3 & 5.2 & 4.3 \\
\hline Sagami-1 & $3459.1^{\prime} \mathrm{N} 13907.1^{\prime} \mathrm{E}$ & 88 & 52.0 & 5.3 & 3.8 \\
\hline Aldrich & & & 46.9 & 3.8 & 0.7 \\
\hline Wako & & & 45.8 & 3.5 & 3.8 \\
\hline
\end{tabular}

The time dependency of the surface tension of marine humic acids is shown in Fig.-1. The surface tension decreases with time; the change was observed for about $10 \mathrm{~h}$ for the higher 
concentration and for more than $150 \mathrm{~h}$ at a con= centration as low as $0.003 \%$. Therefore, the surface tension value was determined when the change reached below $0.1 \mathrm{dyn} \cdot \mathrm{cm}^{-1} \cdot \mathrm{h}^{-1}$.

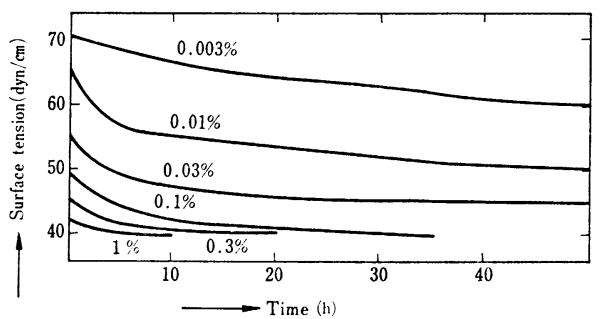

Fig.-1 Time dependence of surface tension of marine humic acid (Sagami-2).

The relation between humic acid concentra $=$ tion and surface tension is presented in Fig.-2. The surface tension decreases linearly in the lower concentration range with the increase in the concentration and becomes constant value of about $40 \mathrm{dyn} / \mathrm{cm}$ at the concentration of $0.1 \%$. The constant values of three samples are inde= pendent of the sampling location and depth; which indicates that the marine humic acids examined are similar in surface active behavior. Commercial humic acids exhibit relatively high surface tension value which means low surface activity of terrestrial humic acids. This character has already pointed out by $\mathrm{Chen}^{4)}$ and Rochus ${ }^{5)}$ for humic acids from peat. The treatment of saponin and bitumen elimination had no effects on the results in Fig.-2. The surface tension of $0.1 \%$ solution decreased with temperature at

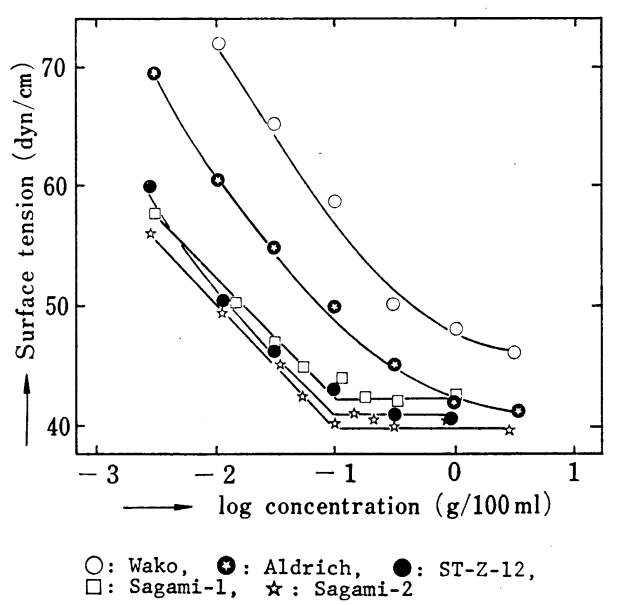

Fig.-2 Relationship between surface tension and concentration. the rate of $2 \mathrm{dyn} / \mathrm{cm} 10^{\circ} \mathrm{C}$; the same tendency as aqueous surfactant solutions. The inflection of the curves in Fig. -2 are analogous to micellar systems. However, the evidence of micellar as= sociation has not yet deen obtained, we call it a bending point (bdp). The bdps of three samples are at the same concentration of $0.1 \%$.

The effects of salts added to humic acid solu= tions are shown in Fig.-3. The bdp of Sagami2 moves to $0.06 \%$ in the presence of $0.1 \% \mathrm{Na}=$ $\mathrm{Cl}$ and to $0.025 \%$ in $1 \% \mathrm{NaCl}$ solution. $\mathrm{Al}=$ though the surface tension at low concentration range decreases, the slope is equal to that of the case without salt. These results are again similar to the salt effect on the ionic surfactant solution.

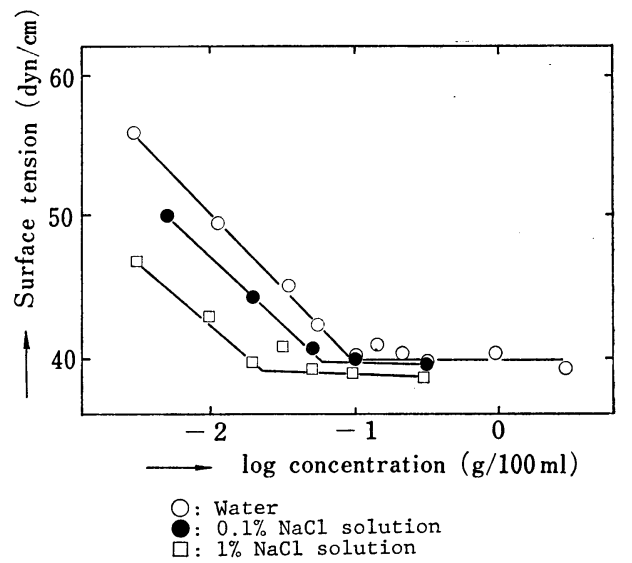

Fig.-3 Salt effect on surface tension of Sagami-2 at $25^{\circ} \mathrm{C}$.

From the measurements described above, it is said that the marine humic acids show marked surface activity compared to that of terrestrial one. The hydrophilic group of the surface ac $=$ tive marine humic acid is thought to be cars boxyl and hydroxyl groups, which were deter= mined by functional group analyses ${ }^{6}$. The fact that the humic acid is a mixture of compounds, molecular weight of which is ranged from few hundreds to few hundreds thousands, may cause the time dependency of surface tension as the bigger compounds need much time to attain equilibrium at the interface. The bending points in the surface tension-concentration curve and the salt effect on the relation indicate the formation of micelle-like aggregate, but to conclude it confirmatory evidence must be necs 
essary ${ }^{9}$.

3.2 Molecular Size Distribution and the Surface Tension of Marine Humic Acids

To examine the effect of molecular size of humic acid on its surface tension, Sagami-2 was fractionated by ultrafiltration; the elemental analysis data are listed in Table-2. Each fracs tion except fraction-E has similar composition to Sagami-2. The surface tension is plotted a gainst concentration in Fig. -4 . The fractions of higher molecular weight, $\mathrm{A}$ and $\mathrm{B}$, behave as a surface active agent and bdps are observed at the concentration of $0.1 \%$ like Sagami-2. Fractions C and D showed low surface activity; the surface tension values were almost the same as those of Wako's humic acid. Because of the

Table-2 Elementary composition of fractions of Sagami-2.

\begin{tabular}{l|c|c|c|c}
\hline Sample & $\begin{array}{c}\mathrm{C} \\
(\%)\end{array}$ & $\begin{array}{c}\mathrm{H} \\
(\%)\end{array}$ & $\begin{array}{c}\mathrm{N} \\
(\%)\end{array}$ & $\begin{array}{c}\text { Content } \\
(\%)\end{array}$ \\
\hline Sagami-2 & 47.9 & 4.8 & 4.8 & \\
A XM 300 & 51.0 & 5.4 & 5.2 & 54.9 \\
B XM 100 & 49.5 & 5.0 & 5.4 & 20.3 \\
C PM 30 & 45.0 & 4.1 & 5.2 & 3.3 \\
D PM 10 & 44.5 & 4.0 & 4.8 & 5.1 \\
E PM & 29.2 & 2.7 & 2.6 & 15.4 \\
\hline
\end{tabular}

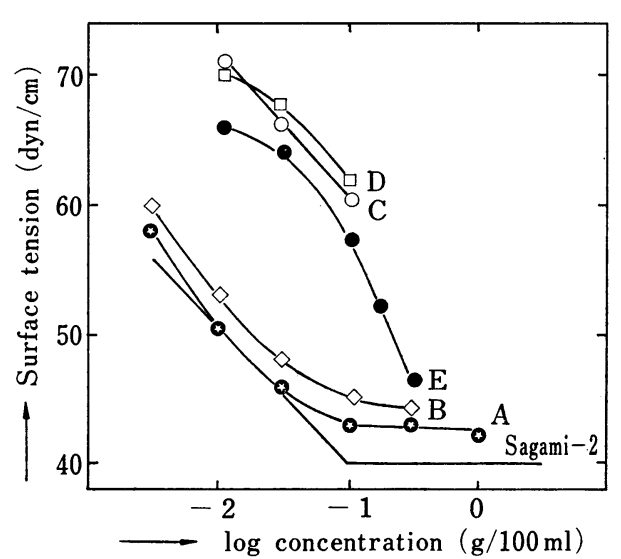

Fig.-4 Surface tension of fractions of Sagami-2 at $25^{\circ} \mathrm{C}$.

small amounts of fraction-C and $-\mathrm{D}$, the sur= face tension in the higher concentration range could not be measured. However, the low sur= face activity will be deduced comparing the value at the concentration of $0.01 \%$ to that of fraction $\mathrm{A}$ at the same concentration. Fraction E, which is thought to be composed of low molecular weight compounds showed low surface tension at the lower concentration but it reached to $47 \mathrm{dyn} / \mathrm{cm}$ at the concentration of $0.3 \%$.

The proportions of fraction $\mathrm{A}, \mathrm{B}, \mathrm{C}, \mathrm{D}$ and $\mathrm{E}$ to the original sample are $54.9 \%, 20.3 \%, 3.3$ $\%, 5.1 \%$ and $15.4 \%$, respectively; fractions A and B occupy $75 \%$ of the sample. The high surface activity of marine humic acids are ap= parently due to these larger molecular size fracs tions.

Chromatograms of various humic acids by 3011 S 35 gel column are shown in Fig.-5. The charge of the gels used in this study neutralized with $0.5 \mathrm{~N} \mathrm{Na}_{2} \mathrm{CO}_{3}$ to depress the ionic repul= sion. The three marine humic acids gave the

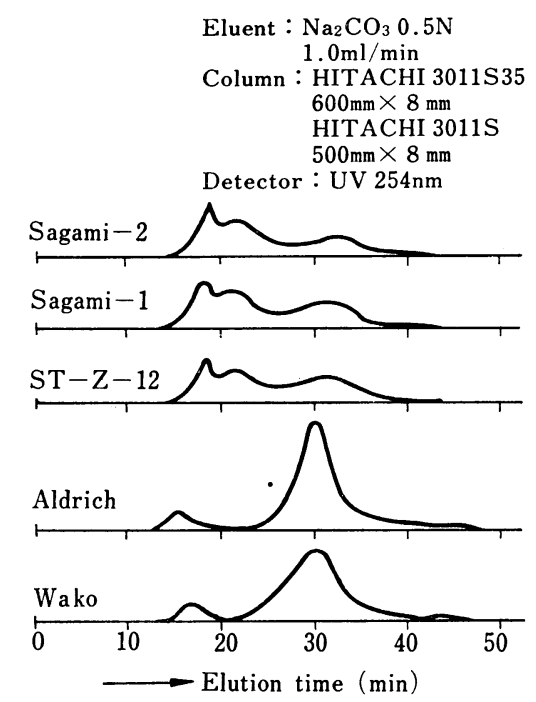

Fig.-5 Chromatograms of humic acids.

similar shape in chromatograms, which may suggest that the nature of these marine humic acids are independent of the sampling location. Three peaks appeared in the chromatogram and they remained unchanged with the changes of flow rate and the sample volume. These chros matograms indicate that the molecular size of the marine humic acids is distributed in the wide range. On the other hand, two peaks were observed in the chromatograms of terres= trial humic acids (Wako and Aldrich); the small peak corresponds the first (large molecular size) 
and the large one to the third peak of marine humic acids. The chromatograms of commercial humic acids resemble each other. Fig. -6 il $=$ lustrates chromatograms for fractionated samples. As for A fraction, the third peak disappears, while with $\mathrm{C}$ and $\mathrm{D}$ fractions are seen the large third peak and the small first peak like those of Wake and Aldrich.

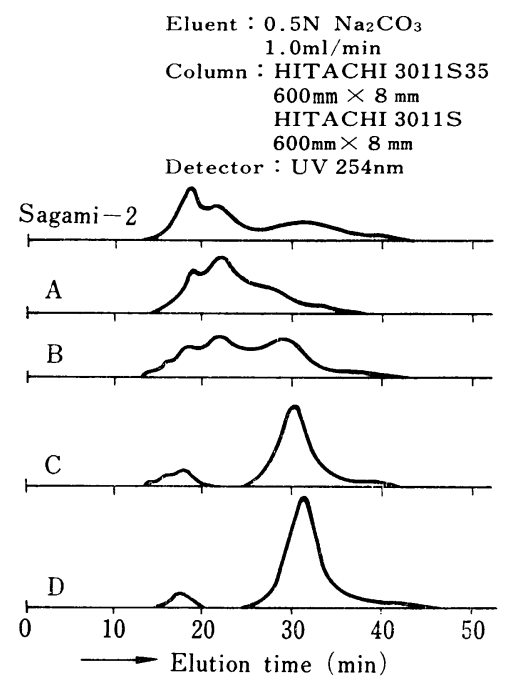

Fig.-6 Chromatograms of fractions of Sagami-2.

The elution profiles of Sagami-2 and its frac= tions by use of $3011 \mathrm{O} 36$ gel are shown in Fig.-7. This gel contains methyrol group in = stead of sulfonate group of 3011 S 35 gel and therefore it behaves less hydrophilic. As illus= trated, Sagmi-2 and A-, B-fractions are strong= ly adsorbed in the gel compared to the weak adsorption of C-, D-fractions. It is assumed that as 3011 O 36 gel is less hydrophilic, the components less hydrophilic are adsorbed on the gel and the strong hydrophilic molecules stay in the solvent water and pass through the col= umn. The different adsorption behavior among the fractions suggests that the higher molecular weight fractions are less hydrophilic than the lower molecular weight fractions and the high surface activity of marine humic acids is given rise toby this low hydrophilic character of the higher molecular weight compounds.

As the humic acid in high concentration was treated for ultrafiltration, aggregates might be possibly formed and which is one of the rea= sons for the high percentage of the higher
Eluent : $0.5 \mathrm{~N} \mathrm{Na}_{2} \mathrm{CO}_{3}$ $1.0 \mathrm{ml} / \mathrm{min}$

Column : HITACHI 3011036

$600 \mathrm{~mm} \times 8 \mathrm{~mm}$

Detector : UV $254 \mathrm{~nm}$

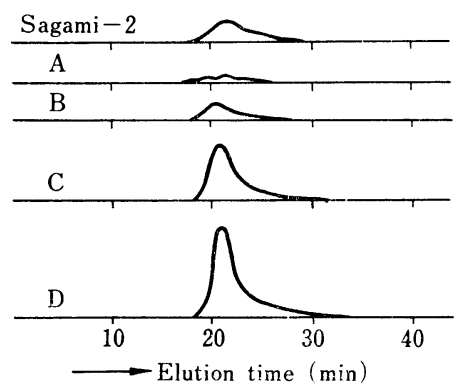

Fig.-7 Chromatograms of fractions of Sagami-2.

molecular weight components. However, mol= ecular weight distribution of each component is comparable to the results of gel chromatography, aggregates may not be dominant in the fraction. The behavior of humic acids in an aqueous solution is still under investigation in our labe oratory.

\section{Conclusion}

1) Marine humic acids have high surface acs tivity compared to commercial humic acids.

2) The marine humic acid may associate at the concentration of more than $0.1 \%$. This concentration is lowered by addition of salt.

3) The marine humic acid is a mixture of compounds of widely ranged molecular weight.

4) The higher molecular weight fraction of a marine humic acid shows higher surface activity than the lower molecular weight fraction.

\section{Acknowledgement}

The authors deeply appreciate Dr. N. Takai and Mr. S. Yoshida for their advice to the chromatogras phic analysis.

(Received Dec. 9, 1981)

\section{References}

1) M. Schnitzer, S.U. Khan, "Humic Substances in the Environment”, Marcel Dekker, Inc., New York (1972), p. 1

2) M. Schnitzer, S.U. Khen, "Humic Substances in the Environment" Marcel Dekker, Inc., New York (1972) p. 3

3) P.D. Boem, J.G. Quinn, Geochimica Cosmochim. Acta, 37, 2459 (1973)

4) Y. Chen, M. Schnitzer, Soil Sci., 125, 7 (1978)

5) W. Pochus, S. Sipos, Agrochimica, XXII, 446, (1978) 
6) Y. Saito, S. Hayano, J. Oceanogr. Soc. Japan, 36, 59 (1980)

7) Y. Saito, S. Hayano, J. Oceanogr. Soc. Japan., 36, 286 (1981)

8) K. Kumada, Soil Sci. Plant Nutr., 11, 11 (1965)

9) D. Attwood, S.P. Agarwal, J. Chem. Soc., Faraday I, 76, 570, (1980)

海洋フミン酸の界面活性

早野茂夫・策塚則子・百武昌夫*

東京大学生産技術研究所 (東京都港区六本木 7-22-1)

* 現在の勤務先・資生堂株式会社

種々のフミン酸溶液の表面張力を測定した。相模湾, 駿河湾の海洋たい積物から $0.5 \mathrm{~N} \mathrm{NaOH}$ で抽出した海 洋フミン酸は，市販の陸成フミン酸に比べて高い界面活
性を示す。表面張力と海洋フミン酸濃度との関係から, 表 面張力は濃度の対数とともに直線的に減少し, 濃度 0.1 \% で約 $40 \mathrm{dyn} / \mathrm{cm}$ の一定值に達する。この $0.1 \%$ 折 れ曲り点は，イオン性界面活性剤のように塩の添加によ って低濃度に移動する。折れ曲り点の存在と, それに対 する塩の効果から, 海洋フミン酸の会合が示唆される。

海洋フミン酸を限外汇過によって分画し, それぞれ分 画分の表面張力を測定した。その結果, 試料の $75 \%$ を 占める高分子量部分が高、界面活性を示し, 表面張力一 濃度曲線には $0.1 \%$ に折れ曲がり点がみられる。

3 種類のゲルを用いてフミン酸の高速液体クロマトグ ラフ分析をすると, フミン酸は広い分子量分布をもった 混合物であることが示される。クロマトグラフ的分子サ イズの分布は限外沪過の結果と大体一致した。海洋フミ ン酸のクロマトグラムから，高分子量成分の親水性が低 く, この弱い親水性が高分子量成分に界面活性を与えて いると思われる。 